\title{
Tulipa kolbintsevii Zonn., a new species from Eastern Kazakhstan
}

\author{
B. J. M. Zonneveld • J. J. de Groot
}

Received: 10 January 2012/ Accepted: 31 March 2012/Published online: 26 April 2012

(c) The Author(s) 2012. This article is published with open access at Springerlink.com

\begin{abstract}
The white-flowered Tulipa kolbintsevii (Liliaceae), section Biflores, occurs in SE Kazakhstan, Dzjungarian Ala-Tau, Taskora valley. So far only $T$. aff. altaica and T. brachystemon (sect. Kolpakowskianae) both with yellow flowers, flushed greenish-violet or red on the outside, were known to be present there. It differs in that it is not only the easternmost species of the section Biflores, and has different placement of hairs on the tepals, but also has the lowest genome size of the species in this section with $2 \mathrm{C}=48 \mathrm{pg}$. The other 14 species have $51.5-59.4 \mathrm{pg}$. Flow cytometry supported morphological differences. This method is useful for identification of dormant bulbs or sterile plants and is therefore important for monitoring of the trade in bulbous species.
\end{abstract}

Keywords Flow cytometry - Tulipa kolbintsevii Zonn. sp. nov $\cdot$ Kazakhstan $\cdot$ Genome size $\cdot 2 \mathrm{C}$ value $\cdot$ Taxonomy

\section{Introduction}

The genus Tulipa L. (Liliaceae) has at least 87 species (Zonneveld 2009). These are divided in four subgenera, Tulipa, Clusianae (Baker) Zonn., Eriostemones (Boiss.) van Raamsd., and Orithyia (D. Don) Baker, and twelve sections (Zonneveld 2009). Genome size and the presence of nearly complete crossing barriers between the sections

B. J. M. Zonneveld ( $\square)$

NBC Naturalis, Herbarium Section, Leiden University, P.O.Box 9514, 2300 RA Leiden, The Netherlands

e-mail: zonneveld@nhn.leidenuniv.nl

J. J. de Groot

Beeklaan 9, 2191 AA De Zilk, The Netherlands
(Van Raamsdonk 1992; Van Raamsdonk and De Vries 1995) confirmed the close relationships of the species within the different sections. Tulips occur naturally in southern Europe, North Africa, the Middle East, and Central Asia, including Western China. The Tien Shan and Pamir-Alay mountain ranges in Central Asia are believed to be the primary gene centres for the species (Botschantzeva 1962), with the Caucasus as a secondary centre. Most species have the same basic chromosome number, $2 \mathrm{n}=2 \mathrm{x}=24$. However, the somatic DNA $2 \mathrm{C}$ value is shown to range from 32 to 69 picogram for the diploids (Zonneveld 2009). They are popular spring-flowering garden plants, millions of bulbs are sold annually and over 5000 cultivars have been registered (Van Scheepen 1996). Despite the existence of a large body of literature on Tulipa, its taxonomy is generally regarded as difficult, as stated in every taxonomic treatment. The main reason is that many character states are polythetic-there is hardly any that is not variable even within a species, only combinations define them: flowering time, the absence or presence and type of hairs on the inside of the bulb tunic, leaf/stem hairiness, flower colour, the absence or presence of a black blotch at the base of the tepals with or without a yellow edge, and whether hairs are present at the base of the filaments. In a previous study DNA $2 \mathrm{C}$ value (nuclear DNA content) was used for analysis of more than 400 different accessions representing nearly all recognized species (Zonneveld 2009).

Nuclear DNA content can conveniently be measured by flow cytometry using propidium iodide, a stoichiometric DNA stain that intercalates in the double helix. Where many species in a genus have the same chromosome numbers, differences in DNA $2 \mathrm{C}$ value have proved to be very effective in delimiting infrageneric divisions in a number of taxa (Ohri 1998; Zonneveld 2009). Moreover, 
Greilhuber (1998, 2005) has clearly shown that intraspecific variation of genome size is much less than assumed.

The smallest angiosperm genome size reported so far is for Genlisea aurea St.Hil. (received and published as G. margaretae Hutch; personal communication, J Greilhuber) (Lentibulariaceae) with $2 \mathrm{C}=0.13 \mathrm{pg}$ (Greilhuber et al. 2006). The record holder for maximum genome size is now, for eudicots, Viscum album L. (Viscaceae) with $2 \mathrm{C}=205.8 \mathrm{pg}$. For monocots, for a short time, the hexaploid Trillium hagae Miyabe and Tatew. (Trilliaceae) with 264.9 pg (Zonneveld 2010a) was the record holder. This value was, a few months later, superseded by its relative, the octoploid Paris japonica Franch. (Trilliaceae) with $2 \mathrm{C}=304.5 \mathrm{pg}$ (Pellicer et al. 2010). Flow cytometry has been successfully used to measure the $2 \mathrm{C}$ value for the genera Agapanthus L'Hér., Eucomis L' Hér., Galanthus L., Helleborus L., Hepatica Mill., Hosta Tratt., Narcissus L., Nerine Herb. and Tulipa L. by Zonneveld (2001, 2008, 2009, 2010a, b, c), Zonneveld and Van Iren (2001), Zonneveld and Duncan (2003, 2006), and Zonneveld et al. (2003). In these papers it was shown that many species can be distinguished by their genome size.

During investigations of the nuclear DNA content $(2 \mathrm{C}$ value) of species of Tulipa (Zonneveld 2009) several were encountered that had genome sizes differing from all other species of their section. They could not be described as new species at that time, because of incomplete material. Tulipa lemmersii Zonn., Peterse \& J. de Groot from the Mashat canyon, Kazakhstan, was provisionally mentioned by Zonneveld (2009) and later validated by Veldkamp and Zonneveld (2012). Here, another interesting new species is reported.

\section{Materials and methods}

Plant material

Plant material was obtained from the collection of $\mathrm{JJ}$ de Groot, De Zilk, The Netherlands.

Flow-cytometric measurement of DNA 2C value

For isolation of nuclei, approximately $1 \mathrm{~cm}$ of leaf was chopped with a piece of Clivia miniata (Lindl.) Regel as internal standard. The material was chopped with a new razor blade in a Petri dish in $0.25 \mathrm{ml}$ nuclei-isolation buffer to which $0.25 \mathrm{mg}$ RNase $/ \mathrm{ml}$ was added (Zonneveld and van Iren 2001). After adding $1.75 \mathrm{ml}$ propidium iodide solution (50 mg PI/l in isolation buffer) the suspension with nuclei was filtered through a $30-\mu \mathrm{m}$ nylon filter. The fluorescence of the nuclei was measured $30 \mathrm{~min}$ and $1 \mathrm{~h}$ after addition of propidium iodide, by use of a Partec CA-II flow cytometer. The optical path contained an HBO mercury lamp, filters KG1 and BG12, dichroic mirror TK500, filter OG570, and a Leitz $50 \times 1$ water-immersion objective. Results were analysed by means of DPAC software (Partec). The 2C DNA content of the sample was calculated as the sample peak mean, divided by the Clivia peak mean, and multiplied with the amount of DNA of the Clivia standard. At least three different samples, each with at least 5000 nuclei, were measured twice. For most histograms the coefficient of variation was $<5 \%$. Fresh male human leucocytes $\left(2 \mathrm{C}=7.0 \mathrm{pg} ; 1\right.$ picogram $=10^{-12} \mathrm{~g}=$ $0.978 \times 10^{9}$ base pairs; Doležel et al. 2003) were chosen as primary standard (Tiersch et al. 1989). This yields $2 \mathrm{C}=39.0 \mathrm{pg}$ for nuclei of Clivia miniata .

\section{Results}

Tulipa kolbintsevii Zonn. sp. nov. Figs. 1, 2, 3, 4.

Tulipae regelii similissima, sed foliis supra non porcatis differt. Orientalissima specierum 15 ceterarum sectionis Biflorium, tepala basi sparse pubescentia secus marginem, demum post meridiem florens.

Nucleo 48 pg tantum ponderenti contra 51.5-59.4 pg in sectionis speciebus ceteris.

Type: Taskora valley, $650 \mathrm{~m}$ Dzjungarian Ala-Tau, Kazakhstan (2010). cult. JJ de Groot s.n. (Holotype L. barcode L 0821329).

Stature tulip erect in all stages, up to $15 \mathrm{~cm}$.

Bulb globose, $20 \mathrm{~mm}$ diam.; tunic pale brown, extension $20 \mathrm{~mm}$ long, inside glabrous, at the neck with some hairs.

Stem erect, glabrous, single flowered, purplish-brown, underground part $10 \mathrm{~cm}$, whitish, supraterrean part c. $12 \mathrm{~cm}$.

Leaves two, canaliculate, greyish green, produced at ground level, glabrous and without cilia, the lower one $145 \times 7 \mathrm{~mm}$, the upper one $130 \times 10 \mathrm{~mm}$.

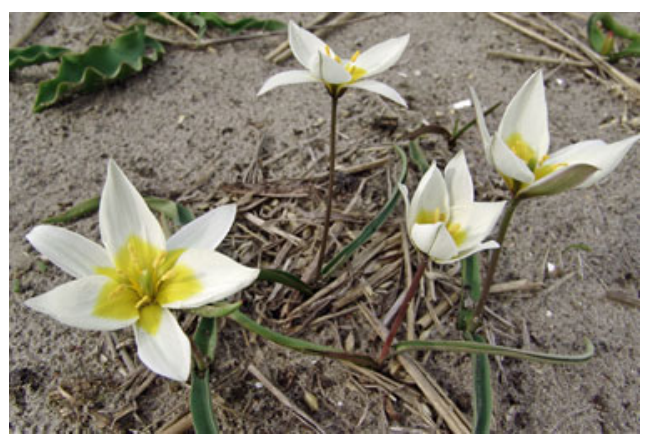

Fig. 1 Tulipa kolbintsevii growing in a garden in de Zilk, The Netherlands (all four pictures are from JJ de Groot) 


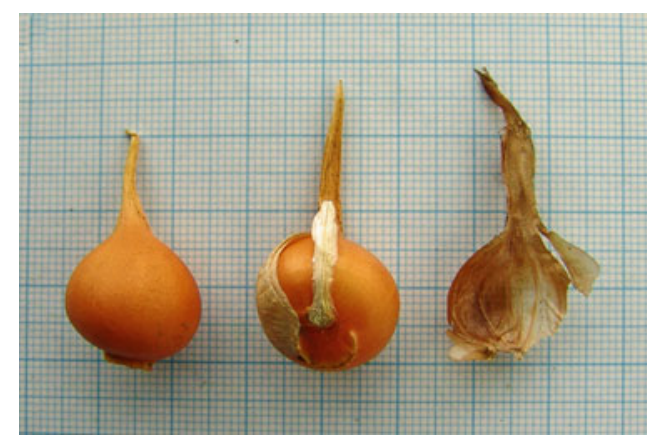

Fig. 2 Bulbs of Tulipa kolbintsevii

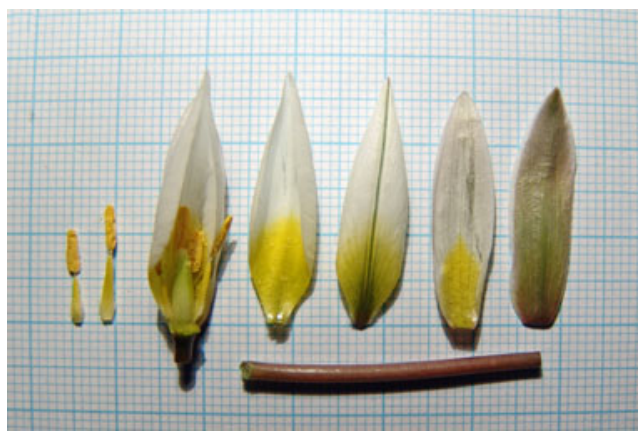

Fig. 3 Details of the dissected flower of Tulipa kolbintsevii

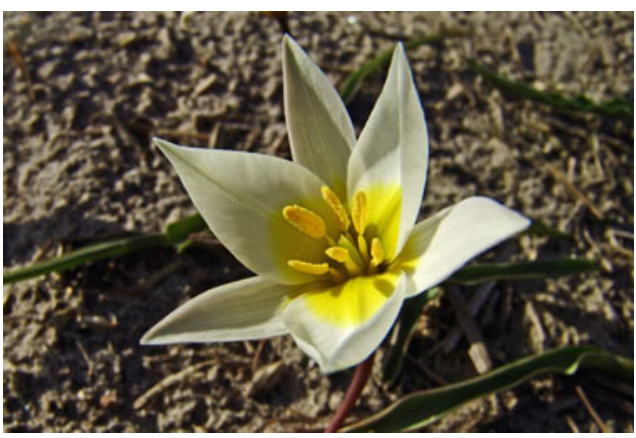

Fig. 4 Details of the expanded flower of Tulipa kolbintsevii

Flower bud straight, obclavate, inner and outer tepals inside white with a whitish-yellow to yellow-orange blotch, c. $2 \mathrm{~cm}$ diam.

Outer tepals $26 \times 7 \mathrm{~mm}$, base margins sparsely hairy, outside greyish-green, in upper part flanked on both sides with a $1 \mathrm{~mm}$ white line and pinkish brown line $1 \mathrm{~mm}$ wide.

Inner tepals $28 \times 8 \mathrm{~mm}$, base margins hairy for $5 \mathrm{~mm}$, outside with a narrow greenish vein, both sides in the upper part with a pinkish brown line.

Stamens longer than the ovary, unequal, 10 and $13 \mathrm{~mm}$ long. Filaments yellow, base hairy in the lower third. Anthers $7 \mathrm{~mm}$ long, yellow, pollen yellow.

Ovary $10 \mathrm{~mm}$ high, green, stigma sessile, yellow-white.
Distribution. Known from its type locality, Taskora valley and adjacent Kolasu valley, Dzjungarian Ala-Tau, East Kazakhstan.

Habitat: Between low bushes, $650 \mathrm{~m}$ alt.

Phenology. Flowering March-April, both in nature and in the garden, opening only at midday similar to T. patens C. Agardh ex Schult $\mathrm{f}$ and T. primulina Baker. (sect. Sylvestres (Baker) Baker).

\section{Discussion}

The Taskora valley at $650 \mathrm{~m}$. in the Dzjungarian Ala-Tau, East Kazakhstan is poor in the number of tulip species. Only $T$. aff. altaica and T. brachystemon have been found so far (Pratov et al. 2006; Ivaschenko 2005). Both have yellow flowers, flushed red or greenish violet on the outside, and belong to section Kolpakowskianae. This new white flowered species belongs to section Biflores AD Hall ex Zonn. and Veldk. which contains 14 other species (Zonneveld 2009). Tulipa kolbintsevii is similar to T. regelii Elwes. in many respects including the bulb, but the latter has unique ridges on the upper side of the leaf. Tulipa kolbintsevii is diploid with a nuclear DNA content of $48.0 \mathrm{pg}$, lower than all the others of the section. These range from 51.5 to $59.4 \mathrm{pg}$ (Zonneveld 2009). It is, moreover, also its easternmost species. The tepals have at the base a hairy edge, not a hairy band, as in the other species of section Biflores.

Etymology. This tulip is dedicated to Vladimir Kolbintsev who, as a guide, accompanied the expedition during which this species was found. He guided many other Dutch tulip expeditions and is an eminent connoisseur of the wild middle Asiatic (tulip) flora and fauna.

Acknowledgments BJMZ would like to thank W Lemmers and JJ de Groot for their excellent advice, based on their hands-on experience. E Boon of Iribov, Heerhugowaard, The Netherlands, is thanked for keeping the flow cytometry apparatus going. JF Veldkamp (L) is thanked for his expert advice on all nomenclatural matters and for careful reading of the manuscript.

Open Access This article is distributed under the terms of the Creative Commons Attribution License which permits any use, distribution, and reproduction in any medium, provided the original author(s) and the source are credited.

\section{References}

Botschantzeva ZP (1962) Tulips: taxonomy, morphology, cytology, phytogeography, and physiology; English edition translated by HQ Varekamp (1982). Balkema, Rotterdam, pp 1-230

Doležel J, Bartos J, Voglmayer H, Greilhuber J (2003) Nuclear DNA content and genome size of trout and human. Cytometry $51: 127-128$ 
Greilhuber J (1998) Intraspecific variation in genome size: a critical reassessment. Ann Bot 82:27-35

Greilhuber J (2005) Intraspecific variation in genome size in angiosperms: identifying its existence. Ann Bot 95:91-98

Greilhuber J, Borsch T, Muller K, Worberg A, Porembski S, Barthlott W (2006) Smallest angiosperm genomes found in Lentibulariaceae with chromosomes of bacterial size. Plant Biol 95:255-260

Ivaschenko A (2005) Tulips and other bulbs of Kazakhstan. Shell Kazakhstan development BV. Two Capitals, Almaty, pp 1-192

Ohri D (1998) Genome size variation and plant systematics. Ann Bot 82(SupplA):750-812

Pellicer J, Fay MF, Leitch IJ (2010) The largest eukaryotic genome of them all? Bot J Linn Soc 164:10-15

Pratov UP, Sharipov A, Ashurmetov OA, Tadjibaev KS (2006) Tulips of the western Tien Shan. Acad Sci Rep Uzbekistan, Tashkent

Tiersch TR, Chandler RW, Wachtel SSM, Ellias S (1989) Reference standards for flow cytometry and application in comparative studies of nuclear DNA content. Cytometry 10:706-710

Van Raamsdonk LWD (1992) Biosystematic studies in Tulipa subgenus Eriostemones. Pl Syst Evol 179:27-41

Van Raamsdonk LWD, De Vries T (1995) Species relationships and taxonomy in Tulipa subgenus Tulipa (Liliaceae). Pl Syst Evol 195:13-44

Van Scheepen J (1996) Classified list and international register of tulip names. KAVB, Hillegom

Veldkamp JF, Zonneveld BJM (2012) The infrageneric nomenclature of Tulipa (Liliaceae). Pl Syst Evol 298:87-92

Zonneveld BJM (2001) Nuclear DNA contents of all species of Helleborus discriminate between species and sectional divisions. Pl Syst Evol 229:125-130
Zonneveld BJM (2008) The systematic value of nuclear DNA content for all species Narcissus L. (Amaryllidaceae). Pl Syst Evol 275:109-132

Zonneveld BJM (2009) The systematic value of nuclear genome size for all species of Tulipa L. (Liliaceae). Pl Syst Evol 281:217-245

Zonneveld BJM (2010a) Genome sizes of Eucomis L'Her. (Hyacinthaceae) and a description of the new species Eucomis grimshawii G.D.Duncan \& Zonn. Pl Syst Evol 284:99-209

Zonneveld BJM (2010) New record holders for maximum genome size in Eudicots and Monocots. Hindawi Publishing Company. J Bot 1-4. doi:10.1155/2010/527357 article ID 527357

Zonneveld BJM (2010) Genome size in Hepatica Mill. (Ranunculaceae) show a loss of DNA not a gain, in polyploids. J Bot 1-7. doi:10.1155/2010/758260 article ID 758260

Zonneveld BJM, Duncan GD (2003) Taxonomic implications of genome size and pollen color and vitality for species of Agapanthus L'Heritier (Agapanthaceae). Pl Syst Evol 241:115-123

Zonneveld BJM, Duncan GD (2006) Genome size for species of Nerine Herb. (Amaryllidaceae) and its evident correlation with growth cycle, leaf width and other morphological characters. Pl Syst Evol 257:251-260

Zonneveld BJM, Van Iren F (2001) Genome size and pollen viability as taxonomic criteria: application to the genus Hosta. Plant Biol 3:176-185

Zonneveld BJM, Grimshaw JM, Davis AP (2003) The systematic value of nuclear DNA content in Galanthus. Pl Syst Evol 241:89-102 